\title{
Možnosti zatiranja izbranih plevelnih vrst v Evropi z žuželkami
}

\author{
Sergeja ADAMIČ ${ }^{1,2}$, Stanislav TRDAN ${ }^{3}$
}

Received January 14, 2020; accepted April 27, 2020.

Delo je prispelo 14. januarja 2020, sprejeto 27. aprila 2020

\begin{abstract}
Možnosti zatiranja izbranih plevelnih vrst $\mathrm{v}$ Evropi $\mathrm{z}$ žuželkami

Izvleček: Zatiranje plevelov z žuželkami je vse bolj pomembno, saj ima kemično zatiranje plevelov (uporaba herbicidov) velik vpliv na okolje in posledično tudi na organizme, ki v njem živijo. Uporaba žuželk za zatiranje plevelov tako predstavlja alternativo herbicidom. V članku so predstavljene možnosti zatiranja nekaterih razširjenih in trdovratnih plevelov v Evropi z njihovimi naravnimi sovražniki - žuželkami. Predstavljene so naslednje kombinacije najpogostejših plevelov in njihovih naravnih sovražnikov: topolistna kislica - ščavje (Rumex obtusifolius L.) - Gastrophysa viridula (De Geer, 1775), kodrastolistna kislica (Rumex crispus L.) - Apion violaceum (Kirby, 1808), pelinolistna ambrozija (Ambrosia artemisiifolia L.) - Ophraella communa (LeSage, 1986) in Zygogramma suturalis (Fabricius, 1775), njivski osat (Cirsium arvense (L.) Scop.) - Cassida rubiginosa (Müller, 1776), plezajoča lakota (Galium aparine L.) - Halidamia affinis (Fallen, 1807) in Sermylassa halensis (Linnaeus, 1767), ptičja dresen (Polygonum aviculare L.) in navadni slakovec (Fallopia convolvulus L.) - Gastrophysa polygoni (Linnaeus, 1758) ter na koncu še njivski slak (Convolvulus arvensis L.) - Galeruca rufa (Germar, 1824) in Tyta luctuosa (Denis in Schiffmuller, 1775).

Ključne besede: pleveli; biotično zatiranje; žuželke; rastlinojede žuželke; povezava žuželka - gostiteljska rastlina; odziv gostitelja; ovipozicija
\end{abstract}

Potential of controlling selected weeds in Europe with insects Abstract: Weed control by insects is increasingly important, as chemical weed control (the use of herbicides) has an important impact on the environment and, consequently, on all organisms living there. The use of insects to control weeds thus represents an alternative to herbicides. The article presents the suppression of some widespread and persistent weeds in Europe with their natural enemies - insects. The following combinations presented below are: broad-leaved dock (Rumex obtusifolius L.) - Gastrophysa viridula (De Geer, 1775), curly dock (Rumex crispus L.) - Apion violaceum (Kirby, 1808), common ragweed (Ambrosia artemisiifolia L.) - Ophraella communa (LeSage, 1986) and Zygogramma suturalis (Fabricius, 1775), creeping thistle (Cirsium arvense (L.) Scop.) - Cassida rubiginosa (Müller, 1776), cleavers (Galium aparine L.) - Halidamia affinis (Fallen, 1807) and Sermylassa halensis (Linnaeus, 1767), common knotgrass (Polygonum aviculare L.) and black-bindweed (Fallopia convolvulus L.) - Gastrophysa polygoni (Linnaeus, 1758) and as the last one field bindweed (Convolvulus arvensis L.) - Galeruca rufa (Germar, 1824) and Tyta luctuosa (Denis in Schiffmuller, 1775).

Key words: weeds; biological control; insects; phytophagous insects; relation insect - host plant; host plant response; oviposition

1 Kmetijski inštitut Slovenije, SI-1000 Ljubljana

2 Korespondenčni avtor, e-naslov: sergeja.adamic@kis.si

3 Univerza v Ljubljani, Biotehniška fakulteta, SI-1000 Ljubljana 


\section{UVOD}

Bistvo biotičnega zatiranja plevela $\mathrm{z}$ žuželkami je, da skušamo zatreti ciljno plevelno vrsto $\mathrm{z}$ vnosom žuželke, primerne glede na gostiteljsko rastlino. Klasično biotično zatiranje plevela je omejeno predvsem na monofagne vrste žuželk (to so tiste, ki se hranijo in preživijo samo na eni vrsti rastlin). Vendar pa pri zatiranju plevelov z žuželkami obstajata dve tveganji. Prvo je, da vnesene žuželke predstavljajo grožnjo za neciljne rastline, medtem, ko je drugo, da žuželka ne bo sposobna učinkovito zatreti ciljnega plevela (Kluge, 2000). Biotično zatiranje plevelov z žuželkami je ena izmed najbolj znanih alternativ kemičnemu zatiranju (Sankaran, 1990). Pri tujerodnih plevelih je potreben dodaten nadzor njihovega širjenja, saj zaenkrat še ni poznanih učinkovitih naravnih sovražnikov za njihovo zatiranje. Veliko samoniklih rastlinskih vrst, ki rastejo v 'domačem' območju razširjenosti, niso obravnavane kot pleveli, ker se pojavljajo $\mathrm{v}$ manjši gostoti in $\mathrm{v}$ razpršenih sestojih, ki jih napadajo različne žuželke. Težave pa se pojavijo, ko se takšne rastline naselijo na novo območje brez naravnih sovražnikov, kjer se začnejo zelo hitro širiti in povečevati gostoto, še posebno, če so za to ugodni tudi drugi okoljski dejavniki (Sankaran, 1990). Zgled takšnega 'divjega' plevela je v Indiji Parthenium hysterophorus L. (Asteraceae). Žuželke, s katerimi zatiramo plevel, le-tega tako poškodujejo, da propade ali pa le prispevajo $\mathrm{k}$ splošnemu zmanjšanju njegove rasti, vigorja in razmnoževalne sposobnosti. Za zatiranje te agresivne plevelne vrste so uporabili različne pristope (mehansko, kemični, biološko), vendar je večina teh pristopov neučinkovitih, ker se ta plevel izjemno hitro širi in raste. Ugotovili so, da je učinkovito zatiranje s hroščem Zygogramma bicolorata (Pallister, 1953), vendar vseeno metoda ni dovolj učinkovita, saj hrošči le-tega tako poškodujejo tako, da prispevajo le $k$ splošnemu zmanjšanju njegove rasti, vigorja in razmnoževalne sposobnosti (Kumar, 2014). Če ena vrsta žuželke ne more zatirati plevela, se lahko za potrebe povečanja učinkovitosti zatiranja uporabi druge (Sankaran, 1990).

Namen pričujočega članka je širjenje informacij o možnostih biotičnega zatiranja plevelov $\mathrm{v}$ Evropi z njihovimi naravnimi sovražniki, ki so na Stari celini domorodni ali splošno razširjeni. Za razliko od nekaterih drugih območij sveta, kjer je uporaba rastlinojedih organizmov za zatiranje plevelov bolj razširjena (zlasti v ZDA) (Bürki in sod., 1997; Pitcairn, 2018), je to področje $v$ Evropi strokovno podhranjeno in ga bo potrebno okrepiti, da bo v prihodnosti mogoča tudi praktična uporaba rastlinojedih organizmov pri zatiranju plevelov. Pleveli, omenjeni v članku, so bili izbrani naključno med vsemi najbolj razširjenimi in najbolj trdovratnimi v Evropi (npr. osat in njivski slak sta še posebej trdovratna zaradi svojih dolgih korenin). Tudi žuželke, naravni sovražniki izbranih plevelov, so bile izbrane na pod- lagi njihove razširjenosti na območju Evrope in pozitivnih izkušenj z njimi pri zatiranju plevela. Raziskovalci so namreč pri vsaki žuželčji vrsti ugotovili sposobnost zatiranja plevelov.

\section{PREGLED DOSEDANJIH OBJAV O USPEŠNOSTI ZATIRANJA IZBRANIH PLEVELOV Z ŽUŽELKAMI}

\subsection{TOPOLISTNA KISLICA - ŠČAVJE (Rumex obtusi- folius L.) IN HROŠČ Gastrophysa viridula (De Geer, 1775)}

\subsubsection{Splošno o hrošču Gastrophysa viridula}

Gastrophysa viridula je vrsta hrošča, ki se v Evropi pojavlja v vseh državah, z izjemo Slovenije, Hrvaške, Luksemburga, Ukrajine, Romunije, Litve, Moldavije, Grčije, Makedonije in Iberskega polotoka. Dolžina teh hroščev se razlikuje med spoloma - samci so dolgi $4 \mathrm{~mm}$ in samice 7 $\mathrm{mm}$. Med parjenjem imajo samice povečan abdomen. Tako samci kot samice so zelene barve s kovinskim sijajem. Za zeleno obarvanost je odgovoren večplastni hitinski sloj, ki se izmenjuje s plastmi, ki vsebujejo melanin. Tudi noge so zelene barve s kovinskim sijajem in močno grajene. Tipalke so nazobčane in srednje dolge. Hrošči so oligofagi, kar pomeni, da se prehranjujejo le z nekaj vrstami rastlin, ki so $\mathrm{v}$ tem primeru različne kislice. Razmnoževalna doba traja od marca do oktobra. Na leto se pojavijo do 4 rodovi, s tem, da zadnji rod prezimi v obliki odraslih hroščev. Samice odložijo več kot 1000 jajčec, ki jihodlagajo v skupine po 20 do 45 skupaj, na spodnjo stran listov gostiteljske rastline. Jajčeca so ovalna, kremne do rumene barve, pred izleganjem pa oranžna. Po 3 do 6 dneh se iz jajčec izležejo ličinke, ki so lahko različnih odtenkov, vse od zelenkasto sive pa do temno rjave. Ličinke dosežejo dolžino do $8 \mathrm{~mm}$. V starejših razvojnih stadijih izločajo snovi, ki odvračajo kompetitorje od hranjenja na listih kislice. Ličinka se zabubi $2 \mathrm{~cm}$ globoko $\mathrm{v}$ tleh in po 6 do 9 dneh se pojavijo odrasli hrošči (Martinková in Honěk, 2004; UK Beetle ..., 2019).

\subsubsection{Biotično zatiranje topolistne kislice $\mathrm{z}$ vrsto $G$. viri- dula}

Zaradi specializiranega načina hranjenja - ličinke in hrošči se hranijo na listih kislice - ta hrošč velja za potencialno 'sredstvo' za zatiranje vrst iz rodu Rumex. Pojavljanje hrošča G. viridula na rastlinah kislice vpliva na zmanjšanje vigorja, ne vpliva pa na propad rastlin. Vpliv tega hrošča na rastline je podkrepljen še z enim biotičnim agensom, rjo Uromyces rumicis (Schumach.) G. Winter (Pucciniaceae). 
Kombinirani vplivi hrošča G. viridula in ostalih biotičnih agensov povečajo propadanje rastlin in s tem prispevajo k njihovem zatiranju (Martinková in Honěk, 2004). Učinkovitost tega hrošča kot biotičnega agensa, je odvisna od intenzivnosti hranjenja in številčnosti hroščev na rastlini. Intenzivnost hranjenja je sorazmerna s kakovostjo listov kislice, ki se proti koncu rastne dobe zmanjšuje. Hranilna vrednost gostiteljskih rastlin se poveča $\mathrm{z}$ rezanjem in ponovno rastjo. Kakovost listov se spreminja tudi zaradi gnojenja $\mathrm{z}$ dušikom in zaradi okužbe $\mathrm{z}$ rjo Uromyces rumicis. Tako gnojenje $\mathrm{z}$ dušikom kot rja Uromyces rumicis zmanjšujeta vsebnost dušika v listih, povečata pa vsebnost ogljika in vode v listih, kar vodi v povečano hranjenje osebkov $G$. viridula $\mathrm{z}$ listi. Okužba $\mathrm{z}$ rjo vpliva na manjše število odloženih jajčec in manjši odstotek izleganja ličink, medtem ko staranje listov vpliva na manjšo vitalnost samic in posledično tudi na manjšo velikost jajčec in sposobnost preživetja ličink. Intraspecifično tekmovanje vpliva tudi na gostoto populacije hroščev. Samice prenehajo z odlaganjem jajčec in zapustijo liste, ki so gosto poseljeni z ličinkami teh hroščev, zaradi izločanja odvračalnih snovi, ki jih tvorijo ličinke. Populacija hrošča G. viridula pogosto s hranjenjem odstrani večji del listov, vendar ponavadi to ne zadostuje za propad celotne rastline. Hatcher (1996) je ugotovil, da tudi majhne rastline kislice ne propadejo ob odstranitvi tudi do $90 \%$ listov. Negativni učinki napada vrste G. viridula se bolj opazni pri rastlinah, izpostavljenih interspecifičnemu tekmovanju. Na številčnost populacije pa vpliva tudi kompleks naravnih sovražnikov, katerih učinkovitost spodbuja raznolikost vegetacije, ki obdaja rastline kislice. Hann in Kromp (2001) sta uporabila tega naravnega sovražnika za biotično zatiranje kislic na travnikih in pašnikih $\mathrm{v}$ sistemih ekološkega kmetijstva. Najbolj učinkovit je bil na nekošenih območjih, kjer kompeticija s travami zmanjša uspešnost rasti kislice. Ta hrošč vpliva na zmanjšano konkurenčno sposobnost in uspeh razmnoževanja rastlin iz rodu Rumex, čeprav je manj učinkovit kot metode rezanja korenin (Martinková in Honěk, 2004).

\subsection{KODRASTOLISTNA KISLICA (Rumex crispus L.) IN HROŠČ Apion violaceum (Kirby, 1808)}

\subsubsection{Splošno o hrošču Apion violaceum}

Apion violaceum je vrsta hrošča, ki se hrani na semenih. V Evropi je bil najden v vseh državah, z izjemo Slovenije, Luksemburga, Estonije, Belorusije, Moldavije, Romunije, Srbije, Makedonije, Črne gore ter Bosne in Hercegovine. V dolžino zraste od 2,6 do 3,5 mm (Schmidt, 2005). Glavne značilnosti, po katerih prepoznamo hrošča, so podolgovato, hruškasto oblikovano telo $\mathrm{z}$ modrimi bleščečimi pokrovkami, debel rilček in razmeroma veliko telo (Mifsudi in
Colonelli, 2010). Samice odlagajo jajčeca na rastline iz rodu Rumex, na navadno ajdo (Fagopyrum esculentum Moench) in na rabarbaro (Rheum rhabarbarum L.). Večina hroščev iz rodu Apion, najdenih v izvrtanih rovih v cvetnem steblu kislice kot ličinke v maju in juniju, se julija ali avgusta preobrazijo v odrasle hrošče (Scott, 1985). Samice odlagajo jajčeca skozi plast pri razvijajočih se cvetovih, stebelne liste in stebla. Ličinke se od mesta izleganja premeščajo po steblu navzdol in gredo skozi tri razvojne stopnje znotraj iste gostiteljske rastline. Prostor za zabubljenje se nahaja na zunanjem delu stebla in se oblikuje tik pred zabubljenjem. Enako kot druge vrste iz rodu Apion, je tudi vrsta $A$. violaceum univoltilna in prezimuje od septembra ali oktobra naprej na tleh v ostankih listov, pod debli,... (Hopkins in Whittaker, 1980). Hopkins in Whittaker (1980) sta v štiriletni raziskavi ugotovila, da se je na dveh opazovanih mestih zmanjšalo število in povprečna višina stebel kodrastolistne kislice , na katerih so bili naseljeni hrošči $A$. violaceum. Sočasno je prišlo tudi do upada števila hroščev, kar sta pripisala zmanjšani višini stebel, kar je vplivalo na privlačnost stebel za samice, ki na njih odlagajo jajčeca. Predvidevala sta, da višina stebel vpliva tako na samice, ki odlagajo jajčeca, kot tudi na preživetje ličink (Grossrieder in Keary, 2004).

\subsubsection{Biotično zatiranje kodrastolistne kislice $\mathrm{z}$ vrsto $A$. violaceum}

Hrošči iz rodu Apion predstavljajo daleč najbolj obetavno metodo biotičnega zatiranja kodrastolistne kislice. S hranjenjem/vrtanjem povzročajo rove na steblih in koreninah (Davies in Turner, 2012). Freese (1995) je preučeval pojavljanje hrošča $A$. violaceum na kodrastolistni kislici in ugotovil, da ta vrsta vrta rove po celotni dolžini stebel. Zgodnost pojavljanja je primerjal z vrsto Apion miniatum Germar, 1833 in ugotovil, da se slednja pojavi dva tedna pred hroščem A. violaceum, to je v začetku maja. Glede gostote hroščev (povprečno število hroščev na steblu) je ugotovil, da je bila ta na istem območju pri vrsti A. violaceum kar štirikrat večja kot pri hrošču A. miniatum, poleg tega je bilo s strani hroščev vrste $A$. violaceum napadenih kar $86 \%$ stebel, medtem ko jih je bilo pri vrsti $A$. miniatum napadenih samo $50 \%$.

2.3 PELINOLISTNA AMBROZIJA (Ambrosia artemisifolia L.) TER HROŠČ AMBROZIJEV LEPENEC Ophraella communa (LeSage, 1986) IN Zygogramma suturalis (Fabricius, 1775)

\subsubsection{Splošno o ambrozijevem lepencu}

Pojav ambrozijevega lepenca so leta 2013 prvič ugo- 
tovili v južni Švici (Ticino) in Severni Italiji (Lombardija) (Boriani in sod., 2013; Müller-Schärer in sod., 2014). Ta vrsta hroščev tam ni domorodna, zato sklepajo, da vzrok tiči v namernem vnosu. Hrošč se je hitro širil po Italiji in se od tam razširil tudi v Slovenijo, na Goriško, kjer so njegov pojav prvič našli v začetku avgusta 2017. Seljak in sod. (2017) so na podlagi obsega napadenega območja, gostote populacije in stopnje poškodovanosti pelinolistne ambrozije sklepali, da se je ambrozijev lepenec na to območje razširil že kakšno leto prej. To so potrdili tudi z izjavami nekaterih ljudi, ki so govorili o močnejših poškodbah pelinolistne ambrozije že leta 2016. Seljak in sod. (2017) dejanski obseg razširjenosti pri nas še ugotavljajo, z veliko gotovostjo pa lahko trdijo, da se bo zagotovo stalno povečeval, saj je hrošč dober letalec. Za zdaj so njegovo zastopanost potrdili v spodnji Vipavski dolini in v dolini Raše na Krasu.

Odrasli hrošči dosežejo velikost od 3,5 do 4,3 mm, pri tem moramo upoštevati, da so samci nekoliko manjši kot samice. Glava, oprsje in pokrovke so rumenkaste do bledo rjavkaste barve. Na temenu glave je podolžna temno rjava lisa. Na predprsju so tri podolžne rjave lise. Pokrovke imajo vdrte pike in podolžne temno rjave proge, ki so izrazitejše pri samicah, medtem ko so lahko samci tudi brez teh prog. Ličinka je vretenasto valjasta, segmentirana, rumeno sivkaste do rumenkaste barve, po bokih po vsaki strani poteka prekinjena rjava proga, noge so črne. Telo je pokrito s številnimi dlačicami, ki so na vrhu betičaste. Razvoj poteka prek treh razvojnih stopenj ličinke v 9 do 12 dneh. Buba je široko jajčasta, zaprta $\mathrm{v}$ značilen zapredek (kokon) iz rjavih vlaken. Jajčece je oranžnorumeno, jajčaste oblike, s kratko zoženim zgornjim delom. Navadno samica jajčeca odloži v skupine po več deset skupaj in na zgornjo stran lista. Ličinka se iz jajčeca razvije v petih dneh (Seljak in sod., 2017). Vrsta prezimi kot odrasel hrošč. Na leto se pojavijo do trije rodovi, na Kitajskem lahko tudi šest (Chen in sod., 2013).

\subsubsection{Splošno o hrošču Zygogramma suturalis}

Zygogramma suturalis izvira iz Severne Amerike, vendar je sedaj naravno zastopan tudi v Evropi, in sicer v Ukrajini, kjer se uporablja za biotično zatiranje ambrozije. Hrošč je majhen in ima rjavo glavo, sredoprsje in pokrovke. Zunanji rob pokrovk je obrobljen s široko umazano rumeno črto, ta rumena črta pa poteka tudi po sredini pokrovk. Na leto se pojavijo do 3 rodovi (prvi na sredini ali konec junija, drugi konec julija ali na začetku avgusta in tretji v začetku ali na sredi septembra), prezimijo pa kot odrasli osebki (Wan in Wang, 1989). Hrošči spet postanejo aktivni pozno $\mathrm{v}$ aprilu ali $\mathrm{v}$ začetku maja in se naselijo na mlade rastlinice ambrozije, ko so te viso- ke le od 2 do $5 \mathrm{~cm}$. Samica v povprečju odloži 394 jajčec (Vinogradova in Bogdanova, 1989).

\subsubsection{Biotično zatiranje pelinolistne ambrozije $\mathrm{z}$ am- brozijevim lepencem in hroščem $Z$. suturalis}

V Avstraliji in na Kitajskem se je kot dolgoročni način zatiranja pelinolistne ambrozije najbolj obneslo klasično biotično zatiranje $\mathrm{z}$ vnosom tujerodnih vrst žuželk z območij naravnega areala rasti pelinolistne ambrozije. Kot najbolj učinkovito vrsto za zatiranje Kiss (2007) smatra hrošča ambrozijevega lepenca, kateri naj bi bil med najbolj znanimi biotičnimi agensi za zatiranje te vrste ambrozije, poleg hrošča $Z$. suturalis.

Glavni gostitelj ambrozijevega lepenca je pelinolistna ambrozija, občasno pa lahko napade tudi sončnice (Helianthus annuus L.), topinambur (Helianthus tuberosus L.), bodiče (Xanthium spp.) in kanadsko hudoletnico (Erigeron canadensis (L.) Cronquist). Ličinke, pa tudi odrasli hrošči, se prehranjujejo $\mathrm{z}$ listi ambrozije in jih pri tem obžrejo vse do debelejših listnih žil, ki se nato navadno posušijo. Posledice namnožitve ambrozijevega lepenca so ponekod zelo očitne. Manj izrazite so neposredne poškodbe še razvijajočih se socvetij, ki pa se navadno ne razvijejo ali se zelo slabo oblikujejo. Pri zelo močnem napadu cela rastlina odmre. Učinek napada je tem večji, čim zgodnejši je napad (se pravi čim mlajše so rastline). Že povsem razvite rastline lahko še vedno oblikujejo okrnjena socvetja iz zaloge hranil v steblu, vendar večinoma ne uspejo oblikovati semena. Biotično zatiranje pelinolistne ambrozije $\mathrm{z}$ ambrozijevim lepencem je dolgoročno najustreznejši in tudi najbolj učinkovit način za omejevanje njenih populacij. Velik razmnoževalni potencial in veliko število rodov zagotavljata zadostno populacijo skozi celotno rastno dobo ambrozije. Na podlagi prvih opazovanj se zdi, da je to daleč najbolj učinkovit način za zatiranje pelinolistne ambrozije (Seljak in sod., 2017).

Odrasli hrošči in ličinke hrošča $Z$. suturalis se hranijo na vrstah Ambrosia artemisiifolia, Ambrosia psilostachya in Ambrosia trifida. Ličinke prvega rodu se začnejo na listih hraniti v sredini maja ali na začetku junija. Ličinke drugega in tretjega rodu pa se začnejo hraniti v prvih dveh tednih avgusta. Reznik in sod. (2008) so škodo na ambroziji v njihovem poskusu opazili le na nekaj parcelah, in sicer v višini do $5 \%$. V okolju brez motenj, ki je stabilno, lahko hrošč $Z$. suturalis povzroči veliko škodo na rastlinah ambrozije v obdobju dveh do treh let, odvisno od začetne gostote rastlin. Večje škode se pojavijo na območjih $\mathrm{z}$ veliko gostoto rastlin ambrozije. Tudi samice raje odlagajo jajčeca na velike in nepoškodovane rastline. Analize Reznika in sod. (1994) so pokazale, da je absolutna gostota hrošča $Z$. suturalis določena $\mathrm{z}$ gosto- 
to rastlin ambrozije. Poljske in laboratorijske raziskave so pokazale, da samice na zelo poškodovanih rastlinah odložijo manjše število jajčec, poleg tega pa je bolj verjetno tudi, da vstopijo v diapavzo, za razliko od tistih na zdravih rastlinah (Vinogradova in Bogdanova, 1989; Reznik, 1989). Reznik (1996) raziskavo zaključi s sklepom, da je bil načrtni vnos hrošča $Z$. suturalis v Rusiji delni in ne popolni uspeh, saj je bilo hranjenje in posledično poškodovanje rastlin pelinolistne ambrozije, $\mathrm{z}$ izjemo nekaj majhnih zaplat rastlin $\mathrm{z}$ veliko gostoto hroščev, premajhno, da bi se na ta način zmanjšala gostota te, že 'toksične', vrste plevela.

\subsection{NJIVSKI OSAT (Cirsium arvense (L.) Scop.) IN HROŠČ Casssida rubiginosa (Müller, 1776)}

\subsubsection{Splošno o hrošču Cassida rubiginosa}

Cassida rubiginosa je vrsta listnega hrošča, ki je bil v Evropi najden v vseh državah, razen na Irskem, v Belorusiji, Moldaviji, Andori in Estoniji. V dolžino meri od 6 do $8 \mathrm{~mm}$, kot vsi hrošči iz rodu Cassida pa ima tudi ta pronotum (sklerenhimski del hrbta na predprsju). Telo hrošča je okroglo, z zelenimi ali rumenozelenimi pokrovkami, pri nekaterih vrstah pa se lahko na hrbtni strani pojavi značilen vzorec v obliki trikotnika. Ličinke so ovalne oblike, rjavkaste ali zelene barve, po robovih na obeh straneh pa so lahko vidne črne dlačice (McLeod in sod., 2015). Na leto se pojavi en rod, prezimijo v obliki odraslih osebkov. Samice v ciklih dolgih 6 tednov odložijo do 1000 jajčec na spodnjo stran listov. Odrasli hrošči živijo do 80 tednov, razvoj od jajčeca do odraslega osebka pa traja 6 tednov (Majka in Lesage, 2008).

\subsubsection{Biotično zatiranje njivskega osata s hroščem $C$. rubiginosa}

Hrošč se hrani na različnih vrstah iz družine Asteraceae, vključno z osati (Cirsium, Carduus, Onopordum) in glavinci (Centaurea) (McLeod in sod., 2015). Odrasle hrošče navadno najdemo na spodnji strani listov, medtem ko se ličinke hranijo na zgornji strani listov. Hrošči se lahko hranijo tudi s cvetnim prahom. Njivski osat je agresivna, invazivna plevelna vrsta in ga je težko zatreti z mehanskimi in kemičnimi pristopi (Liu in sod., 2000). Na Novi Zelandiji je bil leta 2007 hrošč vnesen za potrebe zatiranja njivskega osata in predstavlja enega izmed najbolj obetavnih biotičnih agensov za zatiranje osata (Hettiarachchi in sod., 2018). Cripps in sod. (2019) so ugotovili, da hrošči C. rubiginosa $\mathrm{z}$ objedanjem listov povzročijo precejšnje zmanjšanje gostote populacije in razširjanje njivskega osata $\mathrm{v}$ rastni dobi. Naredili so tudi primerjavo vpliva poškodb hroščev na rastline osata med dvema letoma. Ugotovili so, da se je v obravnavanju, kjer je bilo nanesenih od 10 ali 20 ličink na poganjek, gostota rastlin hitro zmanjšala, kar je $\mathrm{v}$ nasprotju $\mathrm{z}$ drugim opazovanim letom, ko se je gostota poganjkov zmanjšala ne glede na obravnavanje. Oktobra in novembra so opazili najmanj poškodb zaradi hranjenja, vendar se gostota poganjkov in višina rastlin nista zmanjšali. Večje objedanje listov je bilo povezano z zmanjšanim deležem poganjkov, ki so bili sposobni reprodukcije (Cripps in sod., 2019). V kar nekaj raziskavah so potrdili vpliv hranjenja hroščev in ličink v rastni dobi na rastline osata, poleg tega so tudi vse pokazale določen učinek hranjenja na rastlino (npr. zmanjšana višina poganjkov, preživetje in biomasa).

\subsection{PLEZAJOČA LAKOTA (Galium aparine L.) TER GRIZLICA Halidamia afffinis (Fallén, 1807) IN HROŠČ Sermylassa halensis (Linnaeus, 1767)}

\subsubsection{Splošno o grizlici Halidamia affinis}

Grizlica Halidamia affinis, predstavnik reda kožekrilcev, se v Evropi pojavlja povsod, z izjemo Slovenije, Norveške, Portugalske, Ukrajine, Estonije, Litve, Belorusije, Bosne in Hercegovine, Črne gore, Makedonije, Grčije in Albanije. Odrasle grizlice imajo glavo, sredoprsje in krila črno obarvane, $\mathrm{z}$ vmesnimi oranžnimi deli na mezopleuronu (lateralno površje sredoprsja) in izločalnih žlezah. Zadek je oranžen, $\mathrm{z}$ izjemo prvega, drugega in zadnjega segmenta zadka, ki so v večji meri obarvani črno. Noge so oranžne s temno rjavkastim odtenkom. Gosenice so mlečno bele do prozorne. Glava je oranžna s temnimi očmi. Na oprsju so trije pari nog, na zadkovih členih pa je še 8 parov mesnatih izrastkov, ki podobni nogam, imenovani panožice. Grizlice v dolžino dosežejo od 5 do $6,5 \mathrm{~mm}$, najbolj aktivno pa letajo od aprila do junija.

\subsubsection{Splošno o hrošču Sermylassa halensis}

Hrošč Sermylassa halensis je v Evropi zastopan v večini držav, z izjemo Slovenije, Hrvaške, Makedonije, Črne gore, Bosne in Hercegovine, Grčije, Albanije, Portugalske, Irske, Norveške, Finske, Romunije, Moldavije, Latvije, Estonije in Belorusije (Gruev, 2005). V dolžino doseže od 5 do $7 \mathrm{~mm}$. Pokrovke so kovinsko zelene ali modre, redkeje tudi bakrene. Na vrhu glave imajo veliko črno liso. Vratni ščit in noge so rumenorjave barve, tudi oranžne. Prezimijo v razvojnem stadiju jajčec, na območjih z milejšimi zimami tudi kot odrasli osebki. Tipalke so nazobčane in temneje obarvane (UK Beetle ..., 2019). 
2.5.3 Biotično zatiranje plezajoče lakote $\mathrm{z}$ grizlico $H$. affinis in hroščem S. halensis

Odrasle grizlice in pagosenice so oligofagi in se hranijo na rastlinah iz rodu Galium (Pavlinec, 1992). Največjo škodo povzročajo predvsem pagosenice, ki se intenzivno hranijo na listih različnih rastlin iz tega rodu. Ob močnem napadu pagosenic se začnejo rastline sušiti, še pred tem pa se zmanjša fotosintetska sposobnost rastlin (Batra, 1984).

Gostiteljske rastline hrošča $S$. halensis so rastline iz rodov Galium in Clinopodium. Odrasli hrošči se hranijo na listih, medtem ko ličinke najdemo tako na listih kot na steblih. Hrošč velja za potencialni biotični agens za zatiranje plevela zaradi svojih množičnih napadov na rastline iz rodu Galium, pa tudi zaradi povzročitve popolne defoliacije (Pavlinec, 1992).

\subsection{PTIČJA DRESEN (Polygonum aviculare L.) IN NAVADNI SLAKOVEC (Fallopia convolvulus L.) IN HROŠČ Gastrophysa polygoni (Linnaeus, 1758)}

\subsubsection{Splošno o hrošču Gastrophysa polygoni}

Ti hrošči so v Evropi naravno zastopani po celotni Evropi, z izjemo Estonije, Moldavije in Albanije. Čeprav so relativno majhni (4-5 mm), odrasle hrošče na njivah z lahkoto prepoznamo po njihovem oranžnordečem predprsju, nogah in zadku, medtem ko so glava in pokrovke kovinsko zelene ali modre barve. Najpogosteje tega 'listnega' hrošča najdemo na njivah z žiti, kjer se prehranjuje na rastlinah iz družine dresnovk (Polygonum spp., Fallopia spp.) ali na kislicah (Rumex spp.). Prezimijo odrasli hrošči, ki svoja zimska zavetišča zapustijo konec aprila in v začetku maja. Na leto se pojavita dva rodova (lahko pa jih je tudi več). Samica odlaga jajčeca v skupinah, obložena z lepljivo snovjo, na spodnjo stran listov. Število jajčec se razlikuje med rodovi. Bube so dolge od 5 do $5,5 \mathrm{~mm}$, rumene barve $\mathrm{z}$ rjavimi dlačicami, rastočimi v vzporednih črtah. Celoten razvoj prvega rodu traja od 35 do 69 dni, pri drugemu rodu pa 31 do 53 dni (Simpkins, 2012).

\subsubsection{Biotično zatiranje ptičje dresni in navadnega slakovca s hroščem G. polygoni}

Prave gostiteljske rastline hrošča $G$. polygoni so predstavniki iz družine Polygonaceae, predvsem iz rodov Polygonum, Fallopia in Rumex, Clark in sod. (2004) pa so poročali tudi o drugih, naključnih gostiteljskih rastlinah. V Evropi je najpomembnejši gostitelj ptičja dre- sen, občasno pa se pojavi tudi na navadnemu slakovcu. MacNay (1955) meni, da je hrošč G. polygoni koristen, saj s prehranjevanjem na navadnemu slakovcu povzroča njegovo defoliacijo. Kmetje so celo pobirali hrošče in jih načrtno spuščali na njive, kjer je bila velika gostota tega plevela (McDonald, 1956). Popolno defoliacijo so opazili na kar nekaj območjih pokrajine Saskatchewan v Kanadi, največ v njenem zahodno-osrednjem delu (McDonald in sod., 1956).

\subsection{NJIVSKI SLAK (Convolvulus arvensis L.) TER SLAKOV LEPENEC (Galeruca rufa [Germar, 1824]) IN SLAKOV MOLJ (Tyta luctuosa [Denis in Schiffermüller, 1775])}

\subsubsection{Splošno o slakovemu lepencu}

Slakov lepenec je v Evropi zastopan v Italiji. Na leto se pojavijo od 2 do 3 rodovi, in sicer od marca do septembra (Rosenthal in Hostettler, 1980). Prezimijo odrasli hrošči. V dolžino zrastejo 4-8 mm. Pokrovke, glava in vratni ščit so svetlo do temno rjave barve, medtem ko je telo sivorjave barve. Noge so črne barve, tipalke so nitaste in členaste (Rosenthal in Hostettler, 1980).

\subsubsection{Splošno o slakovemu molju}

Slakov molj je v Evropi zastopan v vseh državah, z izjemo Irske, Norveške, Finske in Estonije. Odrasel molj doseže v dolžino $11 \mathrm{~mm}$, razpon kril pa meri od 22 do 25 $\mathrm{mm}$. Sprednji par kril je temno rjave barve, s svetlejšimi črtami, medtem ko je zadnji par kril enakomerne temno rjave barve. Na vseh štirih krilih se pojavlja po ena bela lisa. Rob kril je resast in belo obarvan (Gaoter in sod., 2003). Na leto se pojavita do dva rodova (pozno spomladi in poleti), v toplejših območjih tudi trije. Samica izleže od 400 do 500 jajčec, ki jih najdemo v suhih, peščenih in apnenčastih tleh. Gosenice so rjave, s tremi pari nog na oprsju in štirimi pari panožic. Na vsaki strani njenega telesa poteka po ena svetlejša črta (Doremi, 2019).

\subsubsection{Biotično zatiranje njivskega slaka s slakovim lepencem in slakovim moljem}

Hrošč se hrani samo na rastlinah iz rodov Convolvulus in Calystegia. Zmerna populacija hroščev lahko povzroči defoliacijo, ki je dovolj močna za zmanjšanje števila cvetov na njivskem slaku in posledično manjše število novo zraslih rastlin zaradi manjšega števila semen (Rosenthal in Hostettler, 1980). Pri naravno zasto- 
panih populacijah hroščev se le-ti po pričakovanjih na gostiteljskih rastlinah pojavljajo skozi celo rastno dobo (Rosenthal, 1981). Na njivskem slaku se hranijo tako ličinke kot odrasli hrošči (Rosenthal, 1981), ko pa se ne hranijo jih najdemo na rastlinskih ostankih na površju tal (Rosenthal, 1995).

V ZDA so za biotično zatiranje molja, katerega glavni gostitelj je njivski slak, odločili leta 1980, vendar o njegovem obstanku v okolju niso poročali (Julien, 1992). Tudi rezultati raziskave žuželk v Južni Evropi, povezanih $\mathrm{z}$ njivskim slakom, so razkrili, da je slakov molj eden najbolj razširjenih defoliatorjev, ki ima največji vpliv na zmanjšanje populacije tega plevela (Rosenthal in Buckingham, 1982). Najbolj 'učinkovit' razvojni stadij slakovega molja so gosenice, ki se, v glavnem samo ponoči (Tóth in sod., 2004), hranijo z listi in cvetovi slaka, pri čemer povzročijo zelo veliko škodo (Tóth in Cagáň, 2005; Doremi, 2019).

\section{SKLEPI}

Biotično zatiranje plevela $\mathrm{z}$ žuželkami, pa naj bodo domorodne ali tujerodne, vključuje kompleks medsebojnih vplivov morfoloških, biokemičnih, fenoloških in drugih dejavnikov, tako $\mathrm{v}$ gostiteljski rastlini kot $\mathrm{v}$ žuželki. Specifičnost gostitelja je najpomembnejši pogoj, da se žuželka uporablja kot sredstvo za zatiranje plevela. Medtem ko žuželka na začetku išče ustrezno gostiteljsko rastlino, se odzove na različne dražljaje, sčasoma izbere pravega in ostane na rastlini, ki je najbolj ustrezna za rast in hranjenje. Nekateri taksoni plevelov so odporni na napade določenih žuželk ali pa jih prenesejo, brez, da bi dobili kakšne poškodbe. Lahko pa jih poškodujejo drugi povzročitelji. Več vrst žuželk, ki se pojavljajo na istem plevelu hkrati, vendar kažejo komplementarne in ne tekmovalne navade hranjenja in odlaganja jajčec, ima lahko sinergijski učinek pri zatiranju plevela. Poleg podnebja so biotični dejavniki, kot so paraziti, plenilci in patogeni organizmi, ter biokemične in fenološke spremembe ranljivosti gostiteljskih rastlin med glavnimi vzroki, ki vplivajo na učinkovitost naravnih sovražnikov plevelov (Sankaran, 1990). V Evropi zatiranje plevelov z naravnimi sovražniki, za razliko od nekaterih drugih območij sveta, še ni razširjeno, saj so tovrstne aktivnosti organizacije EPPO usmerjene zlasti v zatiranje gospodarsko škodljivih žuželk in pršic, v prihodnje pa pričakujemo razmah raziskovalnih aktivnosti na področju biotičnega zatiranja plevelov in njihovo postopno vpeljavo v sisteme rastlinske pridelave. Na podlagi pisanja tega preglednega članka smo ugotovili, da bi bile lahko žuželke kot naravni sovražniki plevelov ena od ustreznih alternativ herbicidom.

\section{$4 \quad$ VIRI}

Ang, B. N., Kok, L. T., Holztman, G. I., Wolf, D. D. (1995). Canada thistle [Cirsiujm arvense (L.) Scop.] response to density of Cassida rubiginosa Müller (Coleoptera: Chrysomelidae) and plant competition. Biological control, 5(1), 31-38. https://doi.org/10.1006/bcon.1995.1004

Batra, S. W. T. (1984). Phytophages and pollinators of Galium (Rubiaceae) in Eurasia and North America. Environmental Entomology, 13(4), 1113-1124. https://doi.org/10.1093/ ee/13.4.1113

Boriani, M., Calvi, M., Taddei, A., Tantardini, A., Cavagna, B., Spadoni Andreani, F., ..., Muller-Scharer, H. (2013). Ophraella communa segnalata in Italia su Ambrosia. L'Informatore Agrario, 69(34), 61.

British and Irish sawflies. (2019). Halidamia affinis (Fallén, 1807). Sawflies (Symphyta) of Britain and Ireland: 1 str. https://www.sawflies.org.uk/halidamia-affinis/ (citirano: 17.12.2019)

Bürki, H. M., Schroeder, D., Lawrie, J., Cagan, L., Vrablova, M., ..., Ammon, H. U. (1997). Biological control of pigweeds (Amaranthus retroflexus L., A. Powellii S. Watson and A. bouchonii Thell.) with phytophagous insects, fungal pathogens and crop management. Integrated Pest Management Reviews, 2, 51-59. https://doi.org/10.1023/A:1018480429706

Chen, H., Guo, W., Li, M., Guo, J., Luo, Y., Zhou, Z. (2013). A field test of joint control of the alien invasive weed Ambrosia artemisiifolia with Ophraella communa and Epiblema strenuana. Chinese Journal of Biological Control, 29, 362 369. https://doi.org/10.1080/09583157.2014.897305

Clark, S. M., LeDoux, D. G, Seeno, T. N., Riley, E. G., Gilbert, A. J., Sullivan, J. M. (2004). Beetles listed by plants. V: Host plants of leaf beetle species occurring in the United States and Canada (Coleoptera, Megalopodidae, Orsodacnidae and Chrysomelidae, excluding Bruchinae). Coleopterists Society Special Publication, 2, 258-434. https://doi.org/10.1 603/0013-8746(2005)098[0243:HPOLBS]2.0.CO;2

Cripps, M. G., Jackman, S. D., van Koten, C. (2019). Folivory impact of the biocontrol beetle, Cassida rubiginosa, on population growth of Cirsium arvense. BioControl, 64, 91-101. https://doi.org/10.1007/s10526-018-09915-Z

Davies, G., Turner, B. (2003). Suggestions for biological control of docks in organic farming systems: 8 str. http://citeseerx. ist.psu.edu/viewdoc/download?doi=10.1.1.507.3411\&rep= rep1\&type=pdf (citirano: 19.12.2019)

Doremi, G. (2019). Tyta luctuosa ([Denis \& Schiffermüller], 1775). GDoremi Altervista: 1 str. https://gdoremi. altervista.org/noctuidae/Tyta_luctuosa_en.html (citirano: 18.12.2019)

Freese, G. (1995). Structural refuges in two stem-boring weevils on Rumex crispus. Ecological Entomology, 20(4), 351358. https://doi.org/10.1111/j.1365-2311.1995.tb00467.x

Gaoter, B., Ronkay, L., Fibiger, M. (2003). Noctuidae Europaeae - Catocalinae, Plusiinae. V: Contributions to the systematics of New World macro-moths IV. Schmidt B. C., Lafontaine J. D. (ur.). Entomological Press, 10th edition, SorØ: 452 str.

Grossrieder, M., Kearyy, I. P. (2004). The potential for the biological control of Rumex obtusifolius and Rumex crispus 
using insects in organic farming, with particular reference to Switzerland. Biocontrol News and Information, 25(3), 65-79.

Gruev, B. A. (2005). A comparative list of the leaf beetles of the Balkan countries (Coleoptera: Chrysomelidae). Animalia, 41, 23-46.

Hann, P., Kromp, B. (2001). Ampferregulierung mittels Ampferblattkäfer: erste Ergebnisse. V: 7. Alpenländisches Expertenforum. Bundesanstalt für alpenländische Landwirtschaft Gumpenstein, Irdning: 63-67.

Hatcher, P. E. (1996). The effect of insect-fungus interactions on the autumn growth and over-wintering of Rumex crispus and R. obtusifolius seedlings. Journal of Ecology, 84, 101109. https://doi.org/10.2307/2261704

Hettiarachchi, D. K., Cripps, M. G., Jackman, S. D., van Koten, C., Sullivan, J., Rostás, M. (2018). Tripartite interactions between Cassida rubiginosa and two fungal biocontrol agents on Cirsium arvense: a plant volatile perspective. Bio-Protection (Bioprotection science for New Zealand: 1 str. https://www.researchgate.net/publication/329705986_Tripartite_interactions_between_Cassida_rubiginosa_and_two_fungal_biocontrol_agents_on Cirsium arvense a plant volatile perspective (citirano: 16.12.2019)

Hopkins, M. J. G., Whittaker, J.B. (1980). Interactions between Apion species (Coleoptera: Curculionidae) and Polygonaceae. II. Apion violaceum Kirby and Rumex obtusifolius L. Ecological Entomology, 5(3), 241-247. https://doi. org/10.1111/j.1365-2311.1980.tb01146.x

Igrc, J., DeLoach, J., Zlof, V. (1995). Release and establishment of Zygogramma suturalis F. (Coleoptera: Chrysomelidae) in Croatia for control of common ragweed (Ambrosia artemisiifolia L.). Biological Control, 5, 203-208. https://doi. org/10.1006/bcon.1995.1025

Julien, M. H. (1992). Biological control of weeds: a world catalogue of agents and their target weeds, 3rd edition. CSIRO, Brisbane, Australia: 194 str.

Kluge, R. L. (2000). The future of biological control of weeds with insects: No more 'paranoia', no more 'honeymoon'. Proceedings of the X International Symposium on Biological Control of Weeds. Spencer N. R. (ur.). 4.-14. July 1999, Montana State University, Bozeman, Montana, ZDA: 459467.

Kumar, S. (2014). Spread, menace and management of Parthenium. Indian Journal of Weed Science, 46(3), 205-219.

Lesage, L., Majka, C. G. (2009). Introduced leaf beetles of the Maritime Provinces, 8: Gastrophysa polygoni Linnaeus (Coleoptera: Chrysomelidae). Zootaxa, 2047, 48-62. https://doi.org/10.11646/zootaxa.2047.1.2

Liu, Z., Clay, S. A., Brinkman, M. (2000). Biological control of canada thistle (Cirsium arvense) in South Dakota. Proceedings of the South Dakota Academy of Science, 79, 21-34.

MacNay, C. G. (1955). General-feeding and miscellaneous insects. The Canadian Insect Pest Review, 33, 242-246. https://doi.org/10.11646/zootaxa.2047.1.2

Majka, C. G., Lesage, L. (2008). Introduced leaf beetles of the Maritime Provinces, 7: Cassida rubiginosa Müller and Cassida flaveola Thunberg (Coleoptera: Chrysomelidae).
Zootaxa, 1811, 37-56. https://doi.org/10.11646/zootaxa.1811.1.3

Martinková, Z., Honěk, A. (2004). Gastrophysa viridula (Coleoptera: Chrysomelidae) and biocontrol of Rumex - a review. Plant, Soil and Environment, 50(1), 1-9. https://doi. org/10.17221/3635-PSE

McDonald, H. (1956). Buckwheat - A chrysomelid Gastrophysa polygoni L. The Canadian Insect Pest Review, 34, 168-169.McDonald, H., McMahon, H. A., Putnam, L. G., Stewart, W. W. A., Burrage, R. H., Taylor, M. E., Fredeen, F. J. H. (1956). Insects of the season 1955 in Saskatchewan. The Canadian Insect Pest Review, 34, 26-40.

McLeod, R., Roth, M., Quinn, M. (2015). Species Cassida rubiginosa - Thistle Tortoise Beetle. BugGuide, Iowa State University: 1 str. https://bugguide.net/node/view/13538 (citirano: 16.12 2019)

Mifsud, D., Colonnelli, E. (2010). The Curculionoidea of the Maltese Islands (Central Mediterranean) (Coleoptera). Bulletin of the entomological society of Malta, 3, 55-143.

Müller-Schärer, H., Lommen, S., Rossinelli, M., Bonini, M., Boriani, M., Bosio, G., Schaffner, U. (2014). Ophraella communa, the ragweed leaf beetle, has successfully landed in Europe: fortunate coincidence or threat? Weed Research, 54(2), 109-119. https://doi.org/0.1111/wre.12072

Pavlinec, M. (1992). The significance of phytophagous insects on Galium aparine (Rubiaceae) and other Galium species. V: Mitteilungen der Deutschen Gesellschaft für Allgemeine und Angewandte Entomologie, 8(1-3), 169-173.

Pitcairn, M. J. (2018). Weed biological control in California, USA: review of the past and prospects for the future. BioControl, 63, 349-359. https://doi.org/10.1007/s10526-0189884-6

Reznik, S. Y. (1989). Oviposition selectivity, population density and efficiency of the ragweed leaf beetle Zygogramma suturalis F. Proceedings of the Zoological Institute (Leningrad), 189, 45-55.

Reznik, S. Y. (1996). Classical biocontrol of weeds in crop rotation: a story of failure and prospects for success. Proceedings of the IX International Symposium on Biological Control of Weeds. Moran V. C., Hoffmann J. H. (ur.). 19.-26. januar 1996, Stellenbosch, Južna Afrika, University of Cape Town: 503-506.

Reznik, S. Y., Spasskaya, I. A., Dolgovskaya, M. Y., Volkovitsh, M. G., Zaitzev, V. F. (2008). The ragweed leaf beetle Zygogramma suturalis F. (Coleoptera: Chrysomelidae) in Russia: current distribution, abundance and implication for biological control of common ragweed, Ambrosia artemisiifolia L. XII International Symposium on Biological Control of Weeds: 614-619. https://doi.org/10.1079/9781845935061.0614

Rosenthal, S. S., Hostettler, N. (1980). Galeruca rufa (Col.: Chrysomelidae) seasonal life history and effect of its defoliation on its host plant, Convolvulus arvensis (Convolvulaceae). Entomophaga, 25, 383-390. https://doi.org/10.1007/ BF02374701

Rosenthal, S.S. (1981). European organisms of interest for the biological control of Convolvulus arvensis in the United States. V: Proceedings, 5th International Symposium on Biological Control of Weeds, Brisbane, Australia, 22.-27. julij 1980: 537-544. 
Rosenthal, S. S., Buckingham, R. G. (1982). Natural enemies of Convolvulus arvensis in western Mediterranean Europe. Hilgardia, 5, 1-19. https://doi.org/10.3733/hilg. v50n02p019

Rosenthal, S. S. (1995). Field bindweed (Convolvulus arvensis). V: Biological control in the Western United States. Nechols J. R., Andres L. A., Beardsley J. W., Goeden R. D., Jackson C. G. (ur.). University of California, Division of Agriculture and Natural Resources: 286-288.

Sankaran, T. (1990). Biological control of weeds with insects: A dynamic phenomenon of insect-plant interaction. Proceedings of the Indian Academy of Sciences Animal Sciences, 99(3), 225-232. https://doi.org/10.1007/BF03186392

Schmidt, U. (2005). Perapion violaceum (Kirby, 1808). Kaefer der Welt: 1 str. https://www.kaefer-der-welt.de/perapion violaceum.htm (citirano: 19.12.2019)

Scott, J. K. (1985). Candidate insects for the biological control of Rumex pulcher. V: Proceedings of the 6th International Symposium on Biological Control of Weeds. Vancouver, 19.-25. avgust 1984. Delfosse E. S. (ur.). Ottawa, Agriculture Canada: 829-835.

Seljak, G., Devetak, M., Rot, M., Žežlina, I., Carlevaris, B. (2017). Množični pojav tujerodnega ambrozijevega lepenca (Ophraella communa LeSage) na Goriškem. Kmetijsko gozdarski zavod Nova Gorica: 1 str. https://www.kmetijskizavod-ng.si/panoge/varstvo_rastlin/2017092015322130/ ambrozijev_lepenec_ophraella_communa/_citirano: 13.12.2019)
Simpkins, S. (2012). Some kind of flea or leaf beetle - Gastrophysa polygoni. BugGuide, Iowa State University, Department of entomology: 1 str. https://bugguide.net/node/ view/676482 (citirano: 12.12.2019)

Tóth, P., Tóthová, M., Cagáň, L. (2004). Are there important natural enemies of field bindweed within Slovakian Noctuidae species? Proceedings of the XVI. Slovak and Czech Plant Protection Conference, Slovak Agricultural University, Nitra, Slovakia. Acta fytotechnica et zootechnica, 7, 319-321.

Tóth, P., Cagáň, L. (2005). Organisms associated with the family Convolvulaceae and their potential for biological control of Convolvulus arvensis. Biocontrol News and Information, 26(1), 17-40.

UK Beetle Recording. (2019). Gastrophysa viridula (De Geer, 1775): 1 str. https://www.coleoptera.org.uk/species/gastrophysa-viridula (citirano: 11.12.2019)

UK Beetle Recording. (2019). Sermylassa halensis (Linnaeus, 1767): 1 str. https://www.coleoptera.org.uk/species/sermylassa-halensis (citirano: 18.12.2019)

Vinogradova, E. B., Bogdanova, T. P. (1989). Characteristics of seasonal development of Zygogramma suturalis F. Proceedings of the Zoological Institute (Leningrad), 189, 62-75.

Wan, F. H., Wang, R. (1989). Biology of Zygogramma suturalis (F.) (Col.: Chrysomelidae), an introduced biological control agent of common ragweed, Ambrosia artemisiifolia. Chinese Journal of Biological Control, 5(2), 71-75. 